\title{
ŠVORC P. OD PLUHU DO SENÁTORSKÉHO KRESLA. JURKO LAŽO A JEHO DOBA (1867-1929). PREŠOV: UNIVERSUM, 2018. $271 \mathrm{~S}$. \\ [ШВОРЦ П. ОТ СОХИ ДО СЕНАТОРСКОГО КРЕСЛА. ЮРКО ЛАЖО И ЕГО ЭПОХА (1867-1929). ПРЕШОВ: UNIVERSUM, 2018. 271 C.]
}

\author{
Михаил Юрьевич Дронов - \\ кандидат исторических наук, \\ научный сотрудник, \\ Институт славяноведения \\ Российской академии наук \\ Почтовый адрес: Ленинский проспект, 32А, \\ Москва, 119334, Россия \\ Электронный адрес: mikhaildronov@rambler.ru
}

\section{Аннотация}

Рецензия посвящена новой монографии словацкого историка Петера Шворца о Юрии Лажо (1867-1929). Представляемая книга является скрупулезным исследованием биографии русинского национально-политического активиста на фоне истории карпатских русинов, Австро-Венгрии и Чехословакии. Особое внимание автор уделяет вопросам национальной и конфессиональной идентичности русинского населения Пряшевщины и Подкарпатской Руси. Ю. Лажо вошел в историю в первую очередь как сенатор, представлявший в чехословацком парламенте интересы русинских селян, и борец за переход грекокатоликов в лоно православной церкви. Лажо действовал как последовательный сторонник «общерусского» (общевосточнославянского) национально-языкового направления и критик мадьяризации, а затем словакизации русинов. Монография П. Шворца отличается оригинальностью, автор опирался на документы из различных архивов Словакии, Чехии и Австрии. Несмотря на остающиеся пробелы в биографии Юрия Лажо, книга Петера Шворца является ценным вкладом в историографию темы.

\section{Ключевые слова}

Петер Шворц, православное движение, русины, Чехословакия, Юрий Лажо

Статья поступила в редакцию 15 апреля 2020 г.

Цитирование: Дронов А.M. Švorc P. Od pluhu do senátorského kresla. Jurko Lažo a jeho doba (1867-1929). Prešov: Universum, 2018. 271 s. [Шворц П. От сохи до сенаторского кресла. Юрко Лажо и его эпоха (1867-1929). Прешов: Universum, 2018. 271 с.] // Славянский мир в третьем тысячелетии. 2020. Т. 15. № 1-2. С. 187-192. 


\title{
ŠVORC P. OD PLUHU DO SENÁTORSKÉHO KRESLA. JURKO LAŽO A JEHO DOBA (1867-1929). PREŠOV: UNIVERSUM, 2018. $271 \mathrm{~S}$.
}

\author{
Mikhail Yu. Dronov, \\ Ph.D., Researcher, \\ Institute of Slavic Studies, \\ Russian Academy of Sciences \\ Postal address: Leninsky Prospect 32A, \\ Moscow, 119334 Russia \\ E-mail: mikhaildronov@rambler.ru
}

Abstract

The review is dedicated to the recent monograph by the Slovak historian Peter Švorc on Jurij Lažo (1867-1929). The book is a meticulously researched biography of the Rusyn national political activist set against the background of the history of the Carpathian Rusyns, Austria-Hungary, and Czechoslovakia. The author pays increased attention to the issues of national and confessional identity of the Rusyn population of the Prešov region and Subcarpathian Rus'. J. Lažo went down in history primarily as a Senator who represented the interests of Rusyn villagers in the Czechoslovak Parliament, and as a fighter for the conversion of Greek Catholics to the Orthodox Church. Leger acted as a consistent proponent of the "all-Russian" (all-Eastern Slavic) national-language trend and a critic of the Magyarization and later Slovakization of the Rusyns. All six chapters of the monograph differ in their originality, and are based on documents from various archives in the Slovak Republic, the Czech Republic, and Austria. Despite the remaining gaps in the biography of Jurij Lažo, Peter Švorc's book is a valuable contribution to the historiography of this topic.

Keywords

Czechoslovakia, Jurij Lažo, Peter Švorc, Orthodox movement, Rusyns

Received 15 April 2020.

How to cite: Dronov, M.Yu., 2020. Švorc P. Od pluhu do senátorského kresla. Jurko Lažo a jeho doba (1867-1929). Prešov: Universum, 2018. 271 s. Slavic World in the Third Millennium, vol. 15, no. 1-2, pp. 187-192.

$\bigcup_{1}$ зучение истории русинского нацменьшинства в Словакии (на Пряшевщине) в контексте словацкой историографии принадлежит к числу особенно перспективных и активно развивающихся направлений. Примечательно, что в последние годы русинские сюжеты всё больше привлекают внимание не только исследователей - этнических русинов, но и ученых-историков, не связанных никакими узами ни с русинами, ни с украинцами, ни со словацкими грекокатоликами и православными. Одним из таких авторитетных историков-русинистов является профессор Прешовского университета Петер Шворц (род. 1957). Будучи известным ученым, заместителем председателя Словацкого исторического общества при Словацкой академии наук, по происхождению словаком, а не русином, Шворц вот уже более 20 лет успешно разрабатывает русинские сюжеты. Кроме многочисленных научных статей о русинах в первой половине XX в., его 
перу принадлежат две русинистические монографии, получившие заслуженное признание коллег в Словакии и за ее пределами. Первая книга, «Заколдованная земля», посвящена истории Подкарпатской Руси в 1918 1946 гг. ${ }^{1}$, вторая работа повествует о становлении словацко-подкарпаторусской административной границы в 1919-1939 гг. ${ }^{2}$ Поэтому публикация его очередной монографии вызвала особый интерес. Она посвящена более узкому вопросу, а именно судьбе заметного, хотя и отнюдь не самого выдающегося русинского политика Юрия (Георгия, Юрка) Лажо (1867-1929).

Юрий Лажо вошел в историю в первую очередь как сенатор от Социалдемократической партии (1920-1924 гг.), представлявший интересы русинских селян в чехословацком парламенте, и активный борец за переход («возвращение») грекокатоликов в лоно православной церкви. Лажо родился 3 мая 1867 г. в селе Свидник Шаришского комитата Венгерского королевства - вскоре после образования Австро-Венгрии. До Первой мировой войны будущий политик на некоторое время отправился на заработки в США, после чего с успехом применил полученные трудовые навыки, вернувшись на родину и основав собственную строительную фирму. В традиционно остром для русинов вопросе национальной идентичности и литературного языка Лажо проявил себя как сторонник общерусского (общевосточнославянского) направления и последовательный критик мадьяронства (как известно, ориентация на Венгрию, ее язык и культуру, была особенно популярна в среде грекокатолического духовенства). В 1920-е годы он критиковал и процессы словакизации Пряшевщины. До недавнего времени со взглядами Лажо исследователи знакомились в первую очередь благодаря его брошюре «Русскому народу на Словенску» (Вышний Свидник на Словенску: Типография Ю. Лажо, 1925). Причем до самой этой брошюры, являющейся библиографической редкостью, добирались далеко не все. Большинство русинистов, не говоря о широкой общественности, были вполне удовлетворены приведенным набором фактов, который кочевал из публикации в публикацию.

Ситуация кардинально изменилась с выходом монографии проф. Шворца, который, без преувеличения, представил Ю. Лажо в абсолютно новом, во многом неожиданном свете. В шести главах фундаментального биографического исследования словацкий историк заново, предельно внимательно и критически, пересмотрел вехи жизни русинского политика. П. Шворц опирался на богатый источниковый материал, прежде всего на документы различных архивных хранилищ Словакии (Словацкий национальный архив в Братиславе, Государственный архив в Кошице, Государственный архив в Прешове и др.), Чехии (Архив Канцелярии президента республики, Нацио-

1 Švorc P. Zakliata krajina. Podkarpatská Rus 1918-1946. Prešov: Universum, 1996; Idem. Zakletá zem. Podkarpatská Rus 1918-1946. Praha: Nakladatelství Lidové noviny, 2007.

2 Švorc P. Krajinská hranica medzi Slovenskom a Podkarpatskou Rusou v medzivojnovom období (1919-1939). Prešov: Universum, 2003. 
нальный архив Чешской Республики, Военно-исторический архив в Праге и др.) и Австрии (Австрийский государственный архив в Вене).

Свежий взгляд автора на личность русинского политика присутствует во всех шести главах (учитывая их внутреннюю структурированность, можно сказать - разделов) монографии. При этом автор в рамках повествования не забывает сообщить о фактах не только из биографии самого Лажо, но и из региональной и мировой истории. По сути, это фирменный прием П. Шворца - постоянно чередовать параграфы, посвященные главному герою, с параграфами, касающимися макроконтекста. Последние, пожалуй, даже более насыщены информативно, что только способствует лучшему восприятию текста: подобный подход делает чтение монографии, отвечающей всем критериям академичности, более доступным для новичков в русинистике и широкого круга читателей, по-любительски интересующихся историей.

Уже в первой главе «До вступления в большую политику. Юрко Лажо и его родовые корни» (S. 13-74) П. Шворц сообщил неизвестные подробности из жизни родителей Лажо, описал необычные обстоятельства крещения, которое, к слову, совершил сам Александр Павло́вич (1819-1900) - заметная фигура в пантеоне «карпаторусских будителей». Историк конкретизировал и саму дату рождения будущего политика - 2-е вместо 3-го мая 1867 г., как это обычно приводится в литературе. Здесь же автор привел то немногое, что удалось найти о пребывании Лажо в США и его гражданской позиции в период Первой мировой войны. Известно, что у него, как и у многих его односельчан, был скорее позитивный опыт общения с русскими военными. Это, возможно, и убедило Лажо в национально-языковом единстве «карпатороссов» (сегодня - русинов) и «великороссов» (собственно русских). А как неблагонадежный элемент он некоторое время провел в заключении (конкретное место в рамках Венгерского королевства, к сожалению, пока не удалось установить).

Глава «Юрий Лажо и его вступление в большую политику» (S. 75-138) посвящена первым годам существования Чехословацкой Республики. Большинство русинов, за исключением небольшой прослойки духовенства и учительства, традиционно были заняты в сельском хозяйстве и, как следствие, слабо разбирались в перипетиях политической жизни. Поэтому и первые шаги новоявленных русинских политиков выглядели не всегда умело. Хотя сенаторское кресло, как следует из названия книги, представляется апогеем всей жизненной карьеры Ю. Лажо, показательно, что он удержался в этом самом кресле лишь одну каденцию. Выборы 1925 г. русинский политик из народа проиграл - в том числе, несомненно, изза мощной конкуренции более образованных и «хищных» коллег. Если в 1920 г. Лажо проходил по избирательному списку социал-демократов, то в 1925 г. он уже был кандидатом от Чехословацкой национально-демократической партии. П. Шворц провел в книге детальный разбор личной политической платформы Лажо и ее восприятия современниками. В частности, 
автор доходчиво объяснил, почему одни считали его коммунистом, а другие, особенно при упоминании Лажо уже в годы социализма, относили его к реакционерам. Также любопытны бытовые подробности, например, о поездках Лажо из Свидника на заседания Сената в Прагу.

Глава «Юрий Лажо и административная граница между Словакией и Подкарпатской Русью» (S. 139-166) посвящена проблеме, более всего разделявшей словацких и русинских политиков в межвоенной Чехословакии. Сенатор Лажо отстаивал русинскую точку зрения, добиваясь передачи в состав Подкарпатской Руси Земплинской, Шаришской и Спишской жуп, которые по Сен-Жерменскому мирному договору 1919 г. были включены в словацкую часть нового государства. Инициативы русинов, подробно представленные П. Шворцом, потерпели неудачу.

Глава «Свидницкое “Земледельческое общество” и его основатель» (S. 167-194) повествует о сельскохозяйственной деятельности Ю. Лажо, на которой он сосредоточился после своего провала на выборах. Этот раздел, пожалуй, наиболее насыщен не публиковавшимися ранее архивными источниками. Проф. Шворц детально разобрал историю кооператива, в котором Лажо был сперва почетным, а с 1925 г. действительным председателем. Этот раздел книги будет особенно интересен свидничанам, интересующимся краеведением. Многие из них найдут здесь упоминания состоявших в «Земледельческом обществе» своих предков или предков своих земляков.

Ряд неизвестных подробностей приводится в главе под красноречивым названием «Под микроскопом недоброжелателей» (S. 195-200). Хотя это самая малая по объему глава книги, в ней содержится ценная информация о некоторых судебных разбирательствах, коснувшихся Ю. Лажо.

Принимая во внимание то, что фамилия Лажо у многих ассоциируется прежде всего с процессом перехода русинских униатов в православие, особый интерес вызывает последняя капитола книги: «Юрий Лажо - грекокатолическая и православная церкви» (S. 201-245). Вероятно, многие удивятся, узнав, что у истоков православных симпатий политика были и совсем прозаические причины, а именно финансовый конфликт с местным грекокатолическим деканом (благочинным), переросший в длительную конфронтацию (именно этот пастырь, придерживавшийся венгерских патриотических взглядов, донес на Лажо в годы войны, вследствие чего последний подвергся репрессиям). По иронии судьбы самого Лажо после его преждевременной кончины от простуды отпевал не православный, а грекокатолический священник. К этой же конфессии семья Лажо принадлежит и сейчас. По мнению П. Шворца, указанное обстоятельство свидетельствует о том, что Ю. Лажо никогда официально не переходил в православие. Однако вклад политика, а также носившей его имя типографии в распространение православной веры на Пряшевщине не поддается сомнению.

Автор книги не скрывает, что далеко не все страницы биографии Ю. Лажо удалось осветить с одинаковой тщательностью. Наверное, иссле- 
дование обогатили бы дополнительные источники, например о пребывании героя книги в Северной Америке или о его заключении в годы Первой мировой войны. При этом, несмотря на остающиеся пробелы в жизнеописании Лажо, монография П. Шворца является ценным вкладом в историографию вопроса.

В заключение нельзя не отметить оформление книги. Хотя полиграфия в целом достигла за последние годы заметного прогресса, книга о Лажо представляет собой в этом отношении особый случай. Дело в том, что проф. Шворц, помимо того что занимается исследовательской и преподавательской деятельностью, является директором прешовского издательства «Universum». Поэтому для собственной книги автор не пожалел ни творческих сил, ни средств. Речь идет даже не об обложке, которую украшает фотография внутреннего убранства русинской «хыжы», и не о мелованной бумаге. Практически все главы монографии снабжены уникальными иллюстрациями - документами и фотоматериалами, в том числе из ряда личных архивов.

Неудивительно, что книга П. Шворца была признана «книгой Прешовского самоуправляемого края 2018 г.» в категории профессиональной литературы.

Рекомендую монографию о Ю. Лажо в качестве обязательного чтения всем, кто серьезно интересуется историей карпатских русинов XIX и XX столетий.

\section{Лumepamypa}

Švorc P. Krajinská hranica medzi Slovenskom a Podkarpatskou Rusou v medzivojnovom období (1919-1939). Prešov, 2003. 424 s.

Švorc P. Zakletá zem. Podkarpatská Rus 1918-1946. Praha, 2007. 318 s.

Švorc P. Zakliata krajina. Podkarpatská Rus 1918-1946. Prešov, 1996. 127 s.

\section{References}

Švorc, P., 1996. Zakliata krajina. Podkarpatská Rus 1918-1946. Prešov: Universum. Švorc, P., 2003. Krajinská hranica medzi Slovenskom a Podkarpatskou Rusou v medzivojnovom obdobi (1919-1939). Prešov: Universum.

Švorc, P., 2007. Zakletá zem. Podkarpatská Rus 1918-1946. Praha: Nakladatelství Lidové noviny. 